\title{
New combinations of plant-associated fungi resulting from the change to one name for fungi
}

\author{
Amy Y. Rossman ${ }^{1}$, W. Cavan Allen ${ }^{2,3}$, and Lisa A. Castlebury ${ }^{3}$
}

1'Department of Botany and Plant Pathology, Oregon State University, Corvallis, OR 97331, USA; corresponding author e-mail: amydianer@ yahoo.com

2Department of Plant Pathology, North Carolina State University, Raleigh, NC 27695, USA

${ }^{3}$ Systematic Mycology and Microbiology Laboratory, *USDA-ARS, Beltsville, MD 20705, USA

\begin{abstract}
In advancing to one scientific name for each fungus species, a number of name changes are required especially for plant-associated fungi. These include species names that are not in the correct genus. For example, the generic name Elsinoë is used for fungi causing scab diseases but a number of these species were described in the asexually typified genus Sphaceloma and must be placed in Elsinoë. In other cases species names were determined to be unrelated to the type species of the genus in which they are currently placed and are placed in a more appropriate genus. For each new name the history, rationale and importance of the name is discussed. The following new combinations are made: Acanthohelicospora aurea, A. scopula, Bifusella ahmadii, Botryobasidium capitatum, $B$. rubiginosum, Colletotrichum magnum, Crandallia acuminata, C. antarctica, Elsinoë arachadis, E. freyliniae, E. necator, E. perseae, E. poinsettiae, E. punicae, Entyloma gibbum, Harknessia farinosa, Passalora alocasiae, Protoventuria veronicae, Pseudocercosporella ranunculi, Psiloglonium stygium, Ramularia pseudomaculiformis, Seimatosporium tostum, Thielaviopsis radicicola combs. nov., and Venturia effusa.
\end{abstract}

Key words:

Fungi

nomenclature

plant pathogens pleomorphic fungi scientific names

Article info: Submitted: 10 November 2015; Accepted: 7 January 2016; Published: 11 January 2016.

\section{INTRODUCTION}

In the course of updating the scientific names of plantassociated fungi in the Systematic Mycology \& Microbiology Laboratory Fungal Databases (SMML) to conform with one scientific name for fungi as required by the International Code of Nomenclature for algae, fungi and plants (ICN; McNeill et al. 2012), a number of instances were encountered in which the oldest epithet was not placed in the oldest or preferred genus or for other reasons a name change is required. In the case of species in which the scientific name should be changed but is widely used and applies to economically important plant pathogenic fungi, the name is placed on a list of species names to be protected. This list of proposed protected species names will be evaluated and accepted or declined by the Nomenclature Committee for Fungi (NCF) and put to the 2017 International Botanical Congress for approval. Examples of names proposed for protection are: Balansia claviceps, Helicobasidium purpureum, Lasiodiplodia theobromae, Phanerochaeta chrysosporium, and Venturia inaequalis. A number of lesser known plant-associated fungal

*Mention of trade names or commercial products in this publication is solely for the purpose of providing specific information and does not imply recommendation or endorsement by the U.S. Department of Agriculture. USDA is an equal opportunity provider and employer. names exist for which a new combination is needed and these are made here. Both ascomycetes and basidiomycetes are included, but no members of the Erysiphales, Eurotiales, Saccharomycetales or Uredinales; these groups have been or will be considered elsewhere. In making these new combinations, the basionym and commonly used synonyms are listed but more synonyms may exist as provided in the SMML Fungal Databases (url: http://nt.ars-grin.gov/ fungaldatabases/index.cfm). Here the names are arranged by class. For each name the source of the synonymy is provided as well as the rationale for selection of the genus in which the name is placed.

In this paper there are three situations for which new names are needed. In one case a name was described in a genus but that genus does not have priority or will not be used, thus the name must be placed in the genus to be used. As an example most species originally described in the asexually typified genus Sphaceloma belong in the sexually typified genus Elsinoë because Sphaceloma is now considered a synonym of Elsinoë (Wijayawardene et al. 2014, Rossman et al. 2015). In the second case the sexual and asexual names for a species are synonyms and the oldest epithet is not in the correct genus. This is the situation for Bifusella ahmadii based on Leptostroma admadii for which the younger name $B$. superba is a synonym. The third case is that in which the species are not congeneric with the genus in which they were originally

๑ 2016 International Mycological Association

You are free to share - to copy, distribute and transmit the work, under the following conditions:

Attribution: $\quad$ You must attribute the work in the manner specified by the author or licensor (but not in any way that suggests that they endorse you or your use of the work).

Non-commercial: $\quad$ You may not use this work for commercial purposes.

No derivative works: You may not alter, transform, or build upon this work.

For any reuse or distribution, you must make clear to others the license terms of this work, which can be found at http://creativecommons.org/licenses/by-nc-nd/3.0/legalcode. Any of the above conditions can be waived if you get permission from the copyright holder. Nothing in this license impairs or restricts the author's moral rights. 
placed. As an example Venturia effusa, originally described in Fusicladium, was determined to belong in the genus Venturia but the combination has never been made.

\section{Leotiomycetes}

Bifusella ahmadii (Petr.) Rossman \& W.C. Allen, comb. nov.

MycoBank MB815413

Basionym: Leptostroma ahmadii Petr., Sydowia 8: 181 (1954).

Synonym: Bifusella superba P.F. Cannon \& Minter, Mycol. Pap. 155: 27 (1986).

Notes: When Cannon \& Minter (1986) described Bifusella superba from India, they listed Leptostroma ahmadii as the asexual morph based on their examination of two isosyntype specimens. They also noted that this asexual morph was observed in the type collection of $B$. superba. Minter (1988) suggested that this fungus causes a disease called needle blight of mountain pines known from India and Pakistan. Bifusella Höhn. 1917, typified by B. linearis (Peck) Höhn. 1917, is an accepted genus in Rhytismataceae known primarily from conifers (Hou et al. 2005). The type species of Leptostroma Fr. 1815, L. scirpinum Fr. 1823 on Scirpus, is a synonym of Hypohelion P.R. Johnst. 1990 typified by $H$. scirpinum (DC.) P.R. Johnst. 1990, based on Hypoderma scirpinum DC. 1815, with preference now given to the later generic name (Johnston et al. 2014). Thus, L. ahmadii does not belong in Leptostroma. With the change to one name for fungi, the oldest epithet for the species, L. ahmadii, should be placed in Bifusella.

Crandallia acuminata (Ellis \& Everh.) Rossman \& W.C. Allen, comb. nov.

MycoBank MB815414

Basionym: Duplicaria acuminata Ellis \& Everh., Proc. Acad. Nat. Sci. Philadelphia 47: 429 (1895).

Synonyms: Bifusella acuminata (Ellis \& Everh.) Bonar \& W.B. Cooke, Mycologia 34: 665 (1942).

Crandallia juncicola Ellis \& Sacc., Bull. Torrey Bot. Club 24: 466 (1897).

Crandallia antarctica (Speg.) Rossman \& W.C. Allen, comb. nov.

MycoBank MB 815415

Basionym: Lophodermium antarcticum Speg., Boln. Acad. Nac. Cienc. Córdoba 11: 249 (1887).

Synonym: Duplicaria antarctica (Speg.) P.R. Johnst., Mycol. Pap. 176: 89 (2001).

Notes: The type species of Crandallia Ellis \& Everh. 1897, C. juncicola, is considered the asexual morph of Duplicaria acuminata (Powell 1973), a species that is known from both living and dead stems of primarily Juncus (Juncaceae), also Carex (Cyperaceae), in western North America (Farr \& Rossman 2015, Powell 1973). Through careful developmental studies, Powell (1973) unraveled the relationship of the asexual and sexual morphs of this species, which occur on the same type specimen. The genus Duplicaria Fuckel 1870 is typified by $D$. empetri
(Pers.) Fuckel 1870 on Empetrum (Ericaceae), a species about which little is known. The asexual morph of $D$. empetri was placed in Melasmia by Powell (1973), a genus quite unlike Crandallia. Based on the differences in host family and asexual morphs, it would appear that $D$. empetri is unrelated to C. acuminata, thus Duplicaria and Crandallia are not synonyms. Johnston (2001) compared $D$. acuminata and $D$. antarctica, the two species of Duplicaria on Juncaceae, suggesting that they were congeneric. Although D. acuminata was placed in Bifusella by Bonar \& Cooke (1942), Powell (1973) distinguished these three generic names and rejected Bifusella for Duplicaria acuminata. In addition species of Bifusella including the type species occur only on conifers. Thus Bifusella and Duplicaria are rejected as the possible generic placement for these species. Rather the oldest epithet of each species, including the type species, are now placed in the genus Crandallia.

\section{Dothideomycetes}

Acanthohelicospora aurea (Corda) Rossman \& W.C. Allen, comb. nov.

\section{MycoBank MB815416}

Basionym: Helicomyces aureus Corda, Icon. fung.1: 9 (1837).

Synonyms: Helicosporium aureum (Corda) Linder, Ann. Mo. Bot. Gdn. 16: 279 (1929).

Helicosporium citreoviride Tubaki, Trans. Mycol. Soc. Japan 5: 2 (1964).

Acanthohelicospora scopula (Peck) Rossman \& W.C. Allen, comb. nov.

MycoBank MB815417

Basionym: Acanthostigma scopulum Peck, Bull. N.Y. St. Mus. nat. Hist. 1(2): 22 (1887).

Synonyms: Helicosporium pilosum Ellis \& Everh., Bull. Torrey bot. Club 24: 476 (1897).

[Sphaeria scopula Cooke \& Peck 1880 non Sowerby 1803.]

[Acanthostigmina scopula (Cooke \& Peck) J.L. Crane et al., Canad. J. Bot. 76: 606 (1998).]

[Lasiosphaeria scopula (Cooke \& Peck) Sacc., Syll. Fung. 9: 852 (1891).]

[Tubeufia scopula (Cooke \& Peck) M.E. Barr, Mycotaxon 12: 164 (1980).]

Notes: The genus Acanthohelicospora Boonmee \& K.D. Hyde 2014 was established by Boonmee et al. (2014) based on A. pinicola Boonmee \& K.D. Hyde 2014. They showed that $A$. aurea and $A$. scopula were congeneric but distinct species in this genus, but did not formally make the new combinations. The other potential generic names such as Acanthostigma, Helicomyces, Helicosporium, and Tubeufia were each shown to be distinct from this genus based on the phylogenetic placement of their respective type species. The basionym for $A$. scopula had previously been considered to be Sphaeria scopula Cooke \& Peck 1880 (Réblová \& Barr 2000) but that name is a later homonym of S. scopula Sowerby 1803, thus the basionym for this species dates from the next available name, Acanthostigma scopulum Peck 1887. Both of these epithets are therefore now placed in Acanthohelicospora. 
Elsinoë arachidis (Bitanc. \& Jenkins) Rossman \& W.C. Allen, comb. nov.

MycoBank MB815418

Basionym: Sphaceloma arachidis Bitanc. \& Jenkins, Archos Inst. biol., S. Paulo 11: 45 (1940).

Elsinoë freyliniae (Crous) Rossman \& W.C. Allen, comb. nov.

MycoBank MB815419

Basionym: Sphaceloma freyliniae Crous, Persoonia 25: 125 (2010).

Elsinoë necator (Ellis \& Everh.) Rossman \& W.C. Allen, comb. nov.

MycoBank MB815420

Basionym: Gloeosporium necator Ellis \& Everh., J. Mycol. 3(11): 129 (1887).

Synonyms: Sphaceloma necator (Ellis \& Everh.) Jenk. \& Shear, Phytopathology 36: 1047 (1946).

Plectodiscella veneta Burkholder, Phytopathology 7: 91 (1917).

Elsinoë veneta (Burkh.) Jenkins, J. Agric. Research 44: 696 (1932).

Elsinoë perseae (Jenkins) Rossman \& W.C. Allen, comb. nov.

MycoBank MB815421

Basionym: Sphaceloma perseae Jenkins, Phytopathology 24: 84 (1934)

Elsinoë poinsettiae (Jenkins \& Ruehle) Rossman \& W.C. Allen, comb. nov.

MycoBank MB815422

Basionym: Sphaceloma poinsettiae Jenkins \& Ruehle, Proc. Wash. Acad. Sci. 55: 83 (1942).

Elsinoë punicae (Bitanc. \& Jenkins) Rossman \& W.C. Allen, comb. nov.

MycoBank MB815423

Basionym: Sphaceloma punicae Bitanc. \& Jenkins, Proc. Amer. Sci. Congr. 8: 163 (1942).

Notes: The generic names Elsinoë and Sphaceloma have been applied to the sexual and asexual morphs of the fungi causing scab diseases, which occur primarily in subtropical and tropical regions. In advancing to one scientific name for fungi, it was decided to propose the generic name Elsinoë Racib. 1900, based on E. canavaliae Racib. 1900, for protection over the name used for asexual morphs, Sphaceloma de Bary 1874 based on S. ampelina de Bary 1874 (Wijayawardene et al. 2014, Rossman et al. 2015). Although many names in Sphaceloma need to be recognized in Elsinoë, only the most economically important names of Elsinoë are considered here. Elsinoë arachidis causes a scab disease of peanut in South America that threatens the US peanut industry (Kokalis-Burelle et al. 1997). Elsinoë freyliniae (as $S$. freyliniae) was recently described causing a scab disease of Freylinia (Crous \& Groenewald 2010). Elsinoë necator causes a cane spot or anthracnose of raspberry that occurs in warm temperate and subtropical regions (Sivanesan
\& Critchett 1974). A scab disease of avocado is caused by $E$. perseae, which is widespread in subtropical and tropical regions including Florida (Ploetz et al. 1994). A scab disease on the fruit, leaves and petioles of pomegranate is caused by E. punicae, which occurs throughout its growing range (Farr \& Rossman 2015).

Passalora alocasiae (Syd. \& P. Syd.) Rossman \& W.C. Allen, comb. nov.

MycoBank MB815424

Basionym: Mycosphaerella alocasiae Syd. \& P. Syd., Philipp. J. Sci., C, Bot. 8(3): 195 (1913).

Synonyms: Sphaerella alocasiae (Syd. \& P. Syd.) Trotter, Syll. Fung. 24(2): 850 (1928).

Cercospora caladii var. colocasiae Höhn., Sber. Akad. Wiss. Wien, Math.-naturw. Kl., Abt. 1 116: 150 (1907).

Cercospora colocasiae (Höhn.) Chupp, Monograph of Cercospora: 58 (1954).

Passalora colocasiae (Höhn.) U. Braun, New Zealand J. Bot. 37: 308 (1999).

Phyllosticta colocasiae Höhn., Sber. Akad. Wiss. Wien, Math.-naturw. Kl., Abt. 1 116: 142 (1907).

Notes: When Braun et al. (2014) reviewed the phylogenetic placement and taxonomy of this species, they considered Cercospora caladii var. colocasiae to be the oldest name for this taxon. Because taxa only compete at the same rank (McNeill et al. 2012), the earliest species name available is Phyllosticta colocasiae. However, as that name is already used at species rank in Passalora, the next oldest epithet is provided by Mycosphaerella alocasiae. Based on the generic placement and synonymy in Braun et al. (2014), this oldest available epithet is here placed in Passalora.

Protoventuria veronicae (Bat.) Rossman \& W.C. Allen, comb. nov.

MycoBank MB815425

Basionym: Ramalia veronicae Bat., Revta Biol. (Lisbon) 1(2): 111 (1957).

Synonyms: Fusicladium veronicae (Bat.) B. Sutton \& Pascoe, Aust. Syst. Bot. 1: 81 (1988).

Protoventuria parahebicola Pascoe \& B. Sutton, Aust. Syst. Bot. 3: 281 (1990).

Notes: The sexual morph of Fusicladium veronicae was described as Protoventuria parahebicola (Pascoe \& Sutton 1990), a fungus causing brown leaf blight on Parahebe (Sutton \& Pascoe 1988). With the change to one name for fungi, the oldest epithet must be placed in the accepted genus unless conserved or protected. The genus Protoventuria Berl. \& Sacc. 1887 is typified by P. rosae (De Not.) Berl. \& Sacc. 1887, based on Venturia rosae De Not. 1844, and includes 46 names. Most recently this type species has been regarded as Gibbera rosae (De Not.) E. Müll. \& R. Menon 1955. Zhang et al. (2011) demonstrated that this species, together with $P$. alpina (Sacc.) M.E. Barr 1971, formed a distinct lineage in Dothideomycetes that should be regarded as Protoventuria. The genus Ramalia Bat. 1957, typified by $R$. veronicae, includes only one additional species and has not been widely used. Further, Protoventuria has priority over Ramalia. Fusicladium based on F. pomi is 
considered a synonym of Venturia, a generic name that is proposed for protection (Wijayawardene et al. 2014, Rossman et al. 2015) and is not the correct genus for this species. The name Ramalia veronicae provides the oldest epithet for this species in Protoventuria.

\section{Pseudocercosporella ranunculi (P. Karst.) Rossman}

\& W.C. Allen, comb. nov.

MycoBank MB815426

Basionym: Sphaerella ranunculi P. Karst., Öfvers. K. Svensk. Vetensk.-Akad. Förhandl. 29 (2): 105 (1872).

Synonyms: Mycosphaerella ranunculi (P. Karst.) Lind, Meddr Grønland, Biosc. 71: 167 (1926).

Pseudocercosporella ranunculacearum U. Braun, Mycotaxon 51: 50 (1994).

Notes: Braun (1994, 1995) described the asexual morph Pseudocercosporella ranunculacearum associated with Mycosphaerella ranunculi. Mycosphaerella, typified by $M$. punctiformis, is now considered a synonym of Ramularia based on R. pusilla (Crous et al. 2011), thus the oldest epithet for this species belongs in Pseudocercosporella.

\section{Psiloglonium stygium (Berk. \& M.A. Curtis) Rossman} \& W.C. Allen, comb. nov.

MycoBank MB815427

Basionym: Sporidesmium stygium Berk. \& M.A. Curtis, Grevillea 3: 17 (1874).

Synonyms: Piricauda stygia (Berk. \& M.A. Curtis) R.T. Moore, Rhodora 61: 104 (1959).

Glonium clavisporum Seaver, Mycologia 17: 4 (1925).

Psiloglonium clavisporum (Seaver) E. Boehm et al., Mycol. Res. 113: 469 (2009).

Notes: The generic name Psiloglonium Höhn. 1918, based on P. lineare (Fr.) Petr. 1923, was reinstated by Boehm et al. (2009a, b) including $P$. clavisporum and its asexual morph, Sporodesmium stygium, which provides an older epithet for this species. The genus Sporidesmium, typified by $S$. atrum, is considered a synonym of $S$. ehrenbergii and has been shown to have species scattered throughout Dothideomycetes and Sordariomycetes (Shenoy et al. 2006), but the type was not included in that study. Given the polyphyletic nature of the genus, it would not compete for use with the well-defined Psiloglonium. The genus Piricauda, based on P. uleanum (Sacc. \& P. Syd.) Bubák 1914, now regarded as $P$. paraguayensis (Speg.) R.T. Moore 1959, occurs on the leaf hairs of a tropical tree quite unlike Psiloglonium stygium, which occurs on dead bark (Mercado Sierra et al. 2005). The oldest epithet, S. stygium, must be placed in Psiloglonium and the new combination is made here.

Ramularia pseudomaculiformis (Desm.) Rossman \& W.C. Allen, comb. nov.

MycoBank MB815428

Basionym: Sphaeria pseudomaculiformis Desm., Ann. Sci. Nat., Bot., sér. 3 6: 83 (1846).

Synonyms: Mycosphaerella pseudomaculiformis (Desm.) J. Schröt., in Cohn, Krypt.-Fl. Schlesien 3 (2-3): 337 (1894).
Scolicotrichum bulbigerum Fuckel, Fungi rhenani exsic. no. 1910 (1867).

Phacellium bulbigerum (Fuckel) U. Braun, Nova Hedwigia 50: 509 (1990).

Ramulaspera poterii Ranoj., Bull. Soc. mycol. Fr. 35: 24 (1919).

Notes: Braun (1990) recognized the genus Phacellium Bonord. 1860, based on P. inhonestum Bonord. 1860 and now $P$. alborosellum (Desm.) U. Braun 1990, for synnematous ramularia-like fungi. The genus was monographed by Braun (1998) who included 22 species. He listed Phacellium bulbigerum with Mycosphaerella pseudomaculiformis as the sexual morph with additional synonyms. The genus Phacellium is now considered a synonym of Ramularia based on R. pusilla (Crous et al. 2011). In addition, Mycosphaerella typified by $M$. punctiformis is also considered a synonym of Ramularia (Videira et al. 2015). With the change to one name for species of fungi, this morph provides the oldest epithet for the species, which is here placed in Ramularia.

Venturia effusa (G. Winter) Rossman \& W.C. Allen, comb. nov.

MycoBank MB815429

Basionym: Fusicladium effusum G. Winter, J. Mycol. 1: 101 (1885).

Synonyms: Fusicladosporium effusum (G. Winter) Partridge \& Morgan-Jones, Mycotaxon 85: 364 (2003).

Fusicladium caryigenum Ellis \& Langl., J. Mycol. 4: 124 (1888).

Cladosporium caryigenum (Ellis \& Langl.) Gottwald, Mycologia 74: 388 (1982).

Notes: This widespread species causes pecan scab and other leaf spot diseases of Juglandaceae (Gottwald 1982, Partridge \& Morgan-Jones 2003). It had previously been referred to as Cladosporium caryigenum by Gottwald (1982) while Schubert et al. (2003) considered it a synonym of the older name Fusicladium effusum. Crous et al. (2007) confirmed that Fusicladium effusum belonged in Venturia. Given the extensive use of Venturia, such as $V$. inaequalis for the cause of apple scab and $V$. pyrina for the cause of pear scab, the generic name Venturia is proposed for protection over the generic synonym Fusicladium (Wijayawadene et al. 2014, Rossman et al. 2015). Several species names already placed in Venturia will be protected over their names in Fusicladium, but $F$. effusum does not have a name in Venturia, thus a new combination is made here.

\section{Sordariomycetes}

Colletotrichum magnum (S.F. Jenkins \& Winstead) Rossman \& W.C. Allen, comb. nov.

MycoBank MB815430

Basionym: Glomerella magna S.F. Jenkins \& Winstead, Phytopathology 54: 453 (1964).

Notes: An anthracnose disease of cucurbits was first reported by Jenkins \& Winstead (1964) caused by Colletotrichum magnum (as Glomerella magna). This fungus was the basis 
for a study of appressorium formation (Bhairi et al. 1990) and was recently reported on Lobelia in China ( $\mathrm{Li}$ et al. 2013). With the change to one name for fungal species, the generic name Glomerella is now considered a synonym of Colletotrichum (Cannon et al. 2012). Bhairi et al. (1990: 208) cited the name $C$. magnum, but did not formally combine this epithet in Colletotrichum nor did they cite the basionym as required for valid publication of new combinations by the ICN (McNeill et al. 2012), thus this new combination is formally made here.

Harknessia farinosa (Ellis) Rossman \& W.C. Allen, comb. nov.

MycoBank MB815431

Basionym: Valsa farinosa Ellis, Bull. Torrey bot. Club 9: 99 (1882).

Synonyms: Cryptosporella farinosa (Ellis) Sacc., Syll. Fung. 2: xxxv (1883).

Cryptospora farinosa (Ellis) Ellis \& Everh., N. Amer. Pyren.: 532 (1892).

Wuestneia farinosa (Ellis) J. Reid \& C. Booth, Canad. J. Bot. 67: 889 (1989).

Harknessia caudata Ellis \& Everh., J. Mycol. 1: 92 (1885).

Mastigonetron caudatum (Ellis \& Everh.) Höhn., Sber. Akad. Wiss. Wien, Math.-naturw. Kl., Abt. 1 123: 134 (1914).

Notes: The synonymy presented here follows Nag Raj \& Di Cosmo (1981) and Reid \& Booth (1989) as Harknessia caudata. The type species of Wuestneia Auersw. ex Fuckel 1864, W. aurea Auersw. 1869, belongs in Cryphonectriaceae (Rossman et al. 2007), while most species of Wuestneia have been found to belong in Harknessia (Crous et al. 2012). Harknessia Cooke 1881, typified by $H$. eucalypti Cooke 1881, is included in Harknessiaceae (Crous et al. 2012) in Diaporthales; Wuestneia is not, therefore, the appropriate generic name for this species. The genus Mastigonetron Kleb. 1914, based on M. fuscum Kleb. 1914, was considered a synonym of Harknessia by Nag Raj \& Di Cosmo (1981). This species belongs in the genus Harknessia and is combined into it here using the oldest epithet.

Seimatosporium tostum (Berk. \& Broome) Rossman \& W.C. Allen, comb. nov.

MycoBank MB815432

Basionym: Sphaeria tosta Berk. \& Broome, Ann. Mag. nat. Hist., ser. 2 9: 381 (1852).

Synonymys: Didymella tosta (Berk. \& Broome) Sacc., Syll. Fung.1: 556 (1882).

Paradidymella tosta (Berk. \& Broome) Petr., Ann. mycol. 25: 238 (1927).

Leiosphaerella tosta (Berk. \& Broome) E. Müll., Beitr. Kryptfl. Schweiz 11(2): 672 (1962).

Clethridium tostum (Berk. \& Broome) E. Müll. \& Shoemaker, Canad. J. Bot. 43: 1343 (1965).

Discostroma tostum (Berk. \& Broome) Brockmann, Sydowia 28: 319 (1976).

Didymosphaeria fuckeliana Pass. ex Sacc., Michelia 1: 440 (1878).

Didymella fuckeliana (Pass.) Sacc., First List Cyprus Fungi 1: 556 (1882).
Discosia passerinii Sacc., Syll. Fung. 3: 656 (1884).

Seimatosporium passerinii (Sacc.) Brockmann, Sydowia 28: 320 (1976).

Notes: Brockmann (1976) provided the extensive synonymy for this species, as Discostroma tosta, listing Seimatosporium passerinii as the name for the asexual morph. The generic names Discostroma and Seimatosporium have long been considered names for comparable sexual and asexual morphs (Brockmann 1976, Nag Raj 1993). The type species of Discostroma Clem. 1909, D. rehmii (Schnabl) Clem. 1909, is regarded as Seimatosporium salicinum (Corda) Nag Raj 1993. The type of Seimatosporium Corda 1833, S. rosae Corda 1833 , is a well-known name with many synonyms having a sexual morph described as $D$. rosae Brockmann 1976 (Shoemaker 1964, Brockmann 1976, Nag Raj 1993). Although neither of the type species of Discostroma or Seimatosporium were included, Tanaka et al. (2011) used three species of Discostroma, including $D$. tostum and 11 species of Seimatosporium, to show that representatives of these genera form a monophyletic genus that should be regarded as Seimatosporium. Norphanphoun et al. (2015) added four more isolates of Seimatosporium, including one for the type species $S$. rosae, and also concluded that this genus was monophyletic. Given that Seimatosporium is the oldest name, has priority, has the greater number of species, and is most commonly used, this generic name should be used. A new combination for this common species is therefore required.

Thielaviopsis radicicola (Bliss) Z.W. De Beer \& W.C. Allen, comb. nov.

MycoBank MB815433

Basionym: Ceratostomella radicicola Bliss, Mycologia 33: 468 (1941).

Synonyms: Ceratocystis radicicola (Bliss) C. Moreau, Revue Mycol. 17 (Suppl. Colon. 1): 22 (1952).

Ophiostoma radicicola (Bliss) Arx, Antonie van Leeuwenhoek 18: 211 (1952).

Chalaropsis punctulata Hennebert, Antonie van Leeuwenhoek 33: 334 (1967).

Thielaviopsis punctulata (Hennebert) A.E. Paulin et al., Mycologia 94: 70 (2002).

Notes: In their revision of Thielaviopsis and related genera, De Beer et al. (2014) neglected to place the oldest epithet in the correct genus although this was recognized as necessary. This species causes a serious wilt and root rot disease of palms throughout the world.

\section{Basidiomycota}

Botryobasidium capitatum (Link) Rossman \& W.C. Allen, comb. nov.

MycoBank MB815436

Basionym: Acladium capitatum Link, Mag. Gesell. naturf. Freunde, Berlin 3(1-2): 10 (1809).

Synonyms: Haplotrichum capitatum (Pers.) Link, in Willdenow, Sp. pl., edn 4 6(1): 52 (1824).

Botryobasidium candicans J. Erikss., Svensk bot. Tidskr. 52(1): 6 (1958). 


\section{Botryobasidium rubiginosum (Fr.) Rossman \& W.C.} Allen, comb. nov.

MycoBank MB815434

Basionym: Sporotrichum rubiginosum Fr., Syst. Mycol. 3: 417 (1832) : Fr.

Synonyms: Haplotrichum rubiginosum (Fr.) Hol.-Jech., Česká Mykol. 30: 4 (1976).

Oidium rubiginosum (Fr.) Linder, Lloydia 5: 191 (1942).

Botryobasidium robustior Pouzar \& Hol.-Jech., Česká Mykol. 21: 69 (1967).

Notes: The type of Botryobasidium Donk 1931 is $B$. subcoronatum (Höhn. \& Litsch.) Donk 1931, while Haplotrichum Link 1824, typified by $H$. capitatum Link 1824 , has a sexual morph identified as $B$. candicans J. Erikss. 1959 (Partridge et al. 2001a). With the change to one name for one fungus, Haplotrichum and Botryobasidium are synonyms. Although Haplotrichum is older, Botryobasidium includes more names and is more widely used, thus Botryobasidium is to be propoed for protection over Haplotrichum. Both names are included in Kirk et al. (2013). The connection between $B$. candicans and $H$. capitatum follows Partridge et al. (2001a). The connection between $B$. robustior and $H$. rubiginosum was first discovered by Pouzar \& Holubová-Jechová (1967) who described $B$. robustior as the sexual morph of Oidium rubiginosum, later placing the name in Haplotrichum (Holubová-Jechová 1976). Additional synonyms of this species are included in Partridge et al. (2001b). These new names in Botryobasidium are needed for the above two commonly reported species.

\section{Entyloma gibbum (Fuckel) Rossman \& Castl., comb.} nov.

MycoBank MB815435

Basionym: Ramularia gibba Fuckel, Fungi rhenani exsiccate, no. 1636 (1866).

Synonyms: Entylomella gibba (Fuckel) U. Braun, Monogr. Cercosporella, Ramularia Allied Genera 2: 298 (1998).

Entyloma ranunculi-repentis Sternon, L'heterogenite du Genre Ramularia: 34 (1925).

Entyloma wroblewskii Kochman, Acta Soc. Bot. Pol. 11: 289 (1934).

Entyloma ranunculorum Liro, Ann. Acad. Sci. Fenn., A 42: 111 (1935).

Entyloma ranunculacearum Kochman, PI. Polon. 4: 105 (1936).

Entyloma ranunculi-sclerati Kochman, Pl. Polon. 4: 105 (1936).

Notes: The genus Entyloma de Bary 1874, based on E. microsporum (Unger) J. Schröt. 1874, is a well-known member of Ustilaginales for which the asexual morphs were placed in Entylomella Hohn. 1924, typified by E. ranunculi (Bonord.) Cif. 1924, and now considered Entyloma ficariae A.A. Fisch. Waldh. 1877. Entyloma has priority and is more commonly used than Entylomella. The synonymy for this species is based on Vánky (2011) who recognized Entylomella gibba for the asexual morph of Entyloma ranunculi-repentis. With the change in the ICN (McNeill 2012), the oldest epithet must be placed in the correct genus.

\section{ACKNOWLEDGEMENTS}

We are grateful for the pre-submission comments provided by Pedro Crous and Peter Johnston. In addition we thank Christian Feuillet for assistance with Latin endings.

\section{REFERENCES}

Bhairi S, Buckley EH, Staples RC (1990) Protein synthesis and gene expression during appressorium formation in Glomerella magna. Experimental Mycology 14: 207-217.

Boehm EWA, Mugambi GK, Miller AN, Huhndorf SM, Marincowitz $\mathrm{S}$, et al. (2009a) A molecular phylogenetic reappraisal of the Hysteriaceae, Mytilinidiaceae and Gloniaceae (Pleosporomycetidae, Dothideomycetes) with keys to world species. Studies in Mycology 64: 49-83.

Boehm EWA, Schoch CL, Spatafora JW (2009b) On the evolution of the Hysteriaceae and Mytilinidiaceae (Pleosporomycetidae, Dothideomycetes, Ascomycota) using four nuclear genes. Mycological Research 113: 461-479.

Bonar L, Cooke WB (1942) Some new and interesting fungi from Mt. Shasta. Mycologia 34: 663-668.

Boonmee S, Rossman AY, Lin J-K, Li W-J, Dau D-Q, et al. (2014) Tubeufiales ord. nov, integrating sexual and asexual generic names. Fungal Diversity 68: 239-298.

Braun U (1990) Studies on Ramularia and allied genera (III). Nova Hedwigia 50: 499-521.

Braun U (1994) Studies on Ramularia and allied genera (VII). Nova Hedwigia 58: 191-222.

Braun U (1995) A monograph of Cercosporella, Ramularia and allied genera (phytopathogenic hyphomycetes). Vol. 1. Eching: IHWVerlag.

Braun U (1998) A monograph of Cercosporella, Ramularia and allied genera (phytopathogenic hyphomycetes). Vol. 2. Eching: IHW-Verlag.

Braun U, Crous PW, Nakashima C (2014) Cercosporoid fungi (Mycosphaerellaceae) 2. Species on monocots (Acoraceae to Xyridaceae, excluding Poaceae). IMA Fungus 5: 203-390.

Brockmann I (1976). Untersuchungen ueber die Gattung Discostroma Clements (Ascomycetes). Sydowia 28: 275-338.

Cannon PF, Minter DW (1986) The Rhytismataceae of the Indian subcontinent. Mycological Papers 155: 1-123.

Cannon PF, Damm U, Johnston PR, Weir B (2012) Colletotrichum current status and future directions. Studies in Mycology 73: 181-213.

Crous PW, Groenewald JZ (2010) Sphaceloma freyliniae Crous, sp. nov. Fungal Planet 52: 1-2.

Crous PW, Schubert K, Braun U, de Hoog GS, Hocking AD, et al. (2007) Opportunistic, human-pathogenic species in the Herpotrichiellaceae are phenotypically similar to saprobic or phytopathogenic species in the Venturiaceae. Studies in Mycology 58: 185-217.

Crous PW, Summerell BA, Shivas RG, Carnegie AJ, Groenewald JZ (2012). A re-appraisal of Harknessia (Diaporthales), and the introduction of Harknessiaceae fam. nov. Persoonia 28: 49-65.

Crous PW, Tanaka K, Summerell BA, Groenewald JZ (2011) Additions to the Mycosphaerella complex. IMA Fungus 2: 49-64.

De Beer ZW, Duong TA, Barnes I, Wingfield BD, Wingfield MJ (2014) Redefining Ceratocystis and allied genera. Studies in Mycology 79: 187-219. 
Farr DF, Rossman AY (2015) Fungal Databases, Systematic Mycology and Microbiology Laboratory, ARS, USDA. http:// nt.ars-grin.gov/fungaldatabases/

Gottwald TR (1982) Taxonomy of the pecan scab fungus Cladosporium caryigenum. Mycologia 74: 382-390.

Holubová-Jechová V (1976) Haplotrichum Link instead of Oidium Link, a necessary nomenclatural change. Česká Mykol 30: 3-4.

Hou C-L, Lin Y-R, Piepenbring M (2005) Species of Rhytismataceae on needles of Juniperus spp. from China. Canadian Journal of Botany 83: 37-46.

Jenkins Jr SF, Winstead NN (1964) Glomerella magna, cause of a new anthracnose of cucurbits. Phytopathology 54: 452-454.

Johnston PR (2001) Monograph of the monocotyledon-inhabiting species of Lophodermium. Mycological Papers 176: 1-239.

Johnston PR, Seifert KA, Stone JK, Rossman AY, Marvanova L (2014) Recommendations on generic names competing for use in Leotiomycetes (Ascomycota). IMA Fungus 5: 91-120.

Kirk PM, Stalpers JA, Braun U, Crous PW, Hansen K, et al. (2013) A without-prejudice list of generic names of fungi for protection under the International Code of Nomenclature for algae, fungi, and plants. IMA Fungus 4: 381-443.

Kokalis-Burelle N, Porter DM, Rodriguez-Kabana R, Smith DH, Subrahmanyam P (1997) Compendium of Peanut Diseases, 2nd edn. St Paul, MN: American Phytopathological Society Press.

Li Q-L, Mo J-Y, Huang S-P, Guo T-X, Pan Z-B (2013) First report of leaf spot disease caused by Glomerella magna on Lobelia chinensis in China. Plant Disease 97: 1383.

McNeill J, Barrie FF, Buck WR, Demoulin V, Greuter W, et al. (eds.) (2012) International Code of Nomenclature for algae, fungi, and plants (Melbourne Code). [Regnum Vegetabile no. 154.] Königstein: Koeltz Scientific Books.

Mercado Sierra A, Guarro J, Heredia G (2005) The hyphomycete genus Piricauda, with the description of a new species. Mycological Research 108: 723-728.

Minter DW (1988) Bifusella superba. Descriptions of Pathogenic Fungi and Bacteria 941: 1-2.

Nag Raj TR (1993) Coelomycetous Anamorphs with appendagebearing conidia. Waterloo, ON: Mycologue Publications.

Nag Raj TR, Di Cosmo F (1981) A monograph of Harknessia and Mastigosporella, with notes on associated teleomorphs. Bibliotheca Mycologica 80: 1-62.

Norphanphoun C, Maharachchikumbura SSN, Daranagama A, Bulgakov TS, Bhat DJ, et al. (2015) Towards a backbone tree for Seimatosporium, with S. physocarpi sp. nov. Mycosphere 6: 385-400.

Partridge EC, Baker WA, Morgan-Jones G (2001a) Notes on hyphomycetes. LXXIX. Concerning the Acladium-AlysidiumHaplotrichum complex; nomenclatural nd taxonomic considerations, with redescriptions of respective type species. Mycotaxon 77: 201-214.

Partridge EC, Baker WA, Morgan-Jones G (2001b) Notes on hyphomycetes. LXXXII. A further contribution toward a monograph of the genus Haplotrichum. Mycotaxon 78: 127-160.

Partridge EC, Morgan-Jones G (2003) Notes on Hyphomycetes. $\mathrm{XC}$. Fusicladosporium, a new genus for cladosporium-like anamorphs of Venturia, and the pecan scab-inducing fungus. Mycotaxon 85: 357-370.

Pascoe IG, Sutton BC (1990) Protoventuria parahebicola sp. nov. (Venturiaceae), the teleomorph of Fusicladium veronicae on Parahebe perfoliata. Australian Systematic Botany 3: 281-285.

Ploetz RC, Zentmyer GA, Nishijima WT, Rohrbach KG, Ohr HD (1994) Compendium of Tropical Fruit Diseases. St Paul, MN: American Phytopathological Society Press.

Pouzar Z, Holubová-Jechová V (1967) Botryobasidium robustior spec. nov., a perfect state of Oidium rubiginosum (Fr.) Linder. Česká Mykol 23: 97-101.

Powell PE (1973) The genera Duplicaria (Rhytismataceae) and Crandallia (Leptostromataceae). Mycologia 65: 1356-1370.

Réblová M, Barr ME (2000) The genus Acanthostigma (Tubeufiaceae, Pleosporales). Sydowia 52: 258-285.

Reid J, Booth C (1989) On Cryptosporella and Wuestneia. Canadian Journal of Botany 67: 879-908.

Rossman AY, Farr DF, Castlebury LA (2007) A review of the phylogeny and biology of the Diaporthales. Mycoscience 48: 135-144.

Rossman AY, Crous PW, Hyde KD, Hawksworth DH, Aptroot A, et al. (2015) Recommended names for pleomorphic genera in Dothideomycetes. IMA Fungus 6: 507-523.

Schubert K, Ritschel A, Braun U (2003) A monograph of Fusicladium s. lat. (hyphomycetes). Schlechtendahlia 9: 1-132.

Shenoy BD, Jeewon R, Wu WP, Bhat DJ, Hyde KD (2006) Ribosomal and RPB2 DNA sequence analyses suggest that Sporidesmium and morphologically similar genera are polyphyletic. Mycological Research 110: 916-928.

Shoemaker RA (1964) Seimatosporium (= Cryptostictis) parasites of Rosa, Vitis, and Cornus. Canadian Journal of Botany 42: 411421.

Sivanesan A, Critchett C (1974) Elsinoë fawcetti. Descriptions of Pathogenic Fungi and Bacteria 484: 1-2.

Sutton BC, Pascoe IG (1988) Fusicladium veronicae (Batista), comb. nov., causing brown leaf blight of Parahebe species. Australian Systematic Botany 1: 79-86.

Tanaka K, Endo M, Hirayama K, Okane I, Hosoya T, et al. (2011) Phylogeny of Discosia and Seimatosporium and introduction of Adisciso and Immersidiscosia genera nova. Persoonia 26: 85-98.

Vánky K (2011) Smut Fungi of the World. St Paul, MN: American Phytopathological Society Press.

Videira SIR, Groenewald JZ, Verkley GJM, Braun U, Crous PW (2015) The rise of Ramularia from the Mycosphaerella labyrinth. Fungal Biology 119: 823-843.

Wijayawardene NN, Crous PW, Kirk PM, Wang Y, Woudenberg JHC, et al. (2014) Naming and outline of Dothideomycetes-2014 including proposals for the protection or suppression of generic names. Fungal Diversity 69: 1-55.

Zhang Y, Crous PW, Schoch CL, Bahkali AH, Guo LD, et al. (2011) A molecular, morphological and ecological re-appraisal of Venturiales-a new order of Dothideomycetes. Fungal Diversity 51: 249-277. 